\title{
Heim Pál az Irgalmas Kórházban
}

Annak köszönhetően, hogy fővárosunkban a központi szerepet játszó gyermekkórház 66 éve viseli Heim Pál (1875-1929) nevét, nincs az a laikus, aki ne ismerné e nevet. Az orvostörténelemben már ez is egy jelentős eredmény! A szaksajtóban a neves gyermekgyógyász életéről, múködéséről szinte minden teljességgel elolvasható, de érdekes módon arról, hogy az Irgalmas Kórházban múködött, a közleményekben és lexikonokban is éppen csak névleges említés történik. Úgy tûnik, soha senki nem nézett a dolognak pontosan utána, csak mindenki átvette a tényt. Ugyanakkor a budai Irgalmas Kórház több mint két évszázados múködése közismert, de gyermekgyógyászati múködése feledésbe merült. Ez a szerény dolgozat ennek a hiánynak a betöltésére kíván vállalkozni.

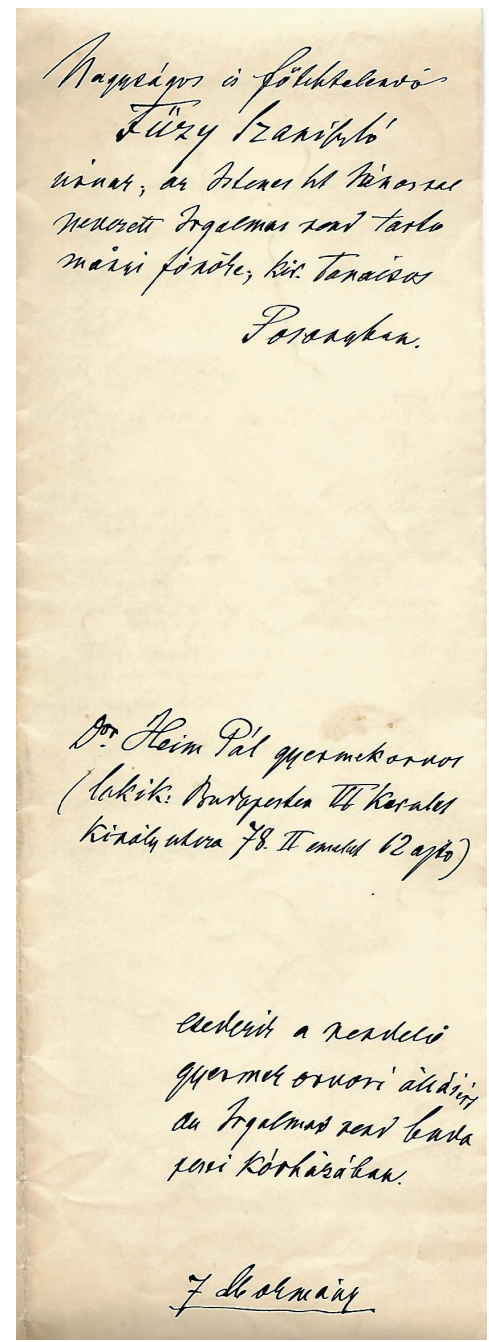

1. ábra

| Heim Pál folyamodványának előzéke
Heim Pál 1897-ben Budapesten, a Tudományegyetemen szerezte meg orvosi oklevelét. Három évvel később, több helyen történt múködése (lásd később) után álláskérelemmel folyamodott az irgalmas rend Pozsonyban székelő magyarországi tartományfőnökéhez, Füzy Szaniszlóhoz (1830-1903). A gyógyszerész végzettségú pozsonyi perjelt 1882-ben, az önálló magyarországi tartomány megalakulásakor választották tartományfónöknek. A folyamodvány előzéklapja az 1 . ábrán látható. A kalligrafikus kézírásos levél két oldalát - az akkori írásmódok bemutatására - szó szerint és betúhíven tesszük közzé:

„Nagyságos és fótisztelendö fönök úr!

A gyermek gyógyászatnak szentelvén magamat, a fötisztelendo" Irgalmasrend budapesti kórházában a rendelo" gyermek orvosi állásért ezennel esedezem.

Budapesti illetôségü, rom. kath. vallású vagyok. Orvosi kiképeztetésemet a 1/a. iratolt orvosi tudori oklevél tanúsága szerint, a budapesti egyetemen nyertem.

1896 évi júl ljétől 1897 évi jul ljéig Dr. Genersich Antal tanár oldala mellett a budapesti egyetem I kórbonctani intézetében müködtem

1897 évi okt ljétöl 1898 évi máj ljéig Dr. Klug Nándor tanár oldala mellett a budapesti egyetem élettani intézetében müködtem

1898 évi máj ho ljétől 1899 évi jul ljéig Dr Bókay János tanár oldala mellett a budapesti Stephania gyermekkórbázban müködtem

1899 évi szept 14dikétôl 1899 évi nov. ljéig Dr. Schlesinger Hermann mag. tanár oldala mellett a bécsi ferenczJozsef Ambulatoriumban müködtem

1899 évi nov 5diktétől 1900 évi feb 26. Czerny Adalbert tanár oldala mellett a boroszlói egyetem ${ }^{1}$ gyermekklinikáján müködtem

1900 évi feb 28dikától 1900 aug. léig Dr. Combe tanár oldala mellett a lausanni egyetem gyermek klinikáján müködtem

1900 évi aug. 5dike óta Dr. Granelet tanár oldala mellett a párisi „Hopital des Enfants malades” gyermekkórbázban müködtem

Ezen idö alatt a következö dolgozataim jelentek meg: (felsorol hármat és megemlíti a megjelenés alatt lévőket)

Hogy tudományos müködésemet szakadatlanul folytathassam, esedezem a fötisztelendö Rend budapesti kórházi rendelö gyermekorvosi állásáért.

Budapest, 1900 évi”

$\mathrm{Az}$ eredeti kordokumentumból szokatlan és érdekes stiláris dolgok olvashatók ki. 1. Az állásért folyamodó megismételten „esedezem” szóhasználata. 2. A dátumok 


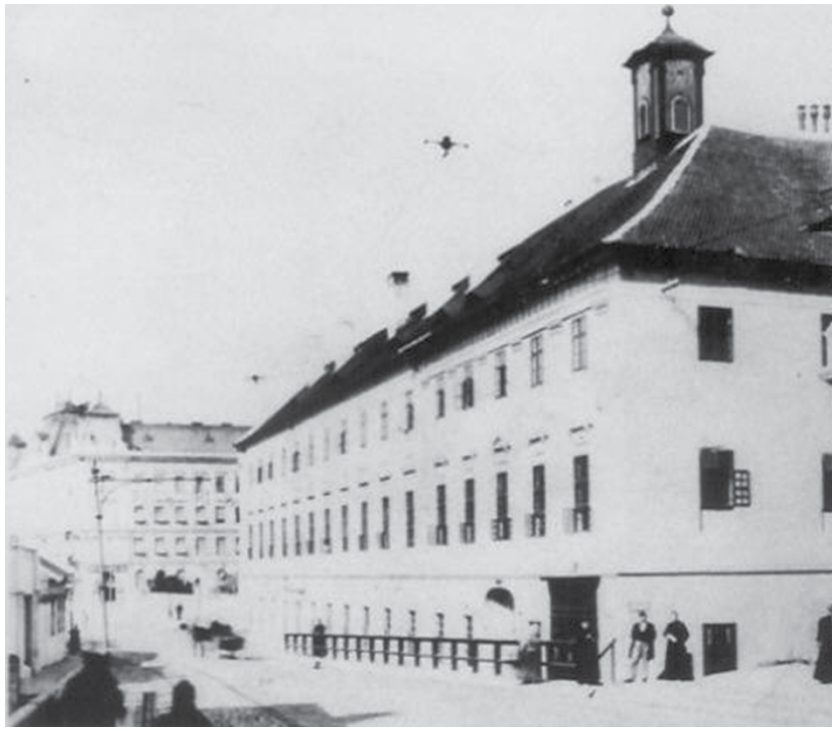

2. ábra akkori szokás szerinti írása. 3. Mai szemmel furcsa helyesírások: „Stephania”, „ferenc-Jozsef”. 4. Minden alkalommal XY „oldala mellett” múködött kifejezés használata. 5. A kérelem dátummal végződik, de nem szerepel rajta hó és nap. - Fontosabbnak tûnnek azonban a tartalmi megállapítások. Tehát Heim Pál 3 évi, több helyen eltöltött gyakorlat után önálló ambuláns állásra pályázott. Részéről a kórházi orvosi állás elfoglalásának fó érve tudományos munkájának a folytatása volt.

De hová is pályázott Heim Pál? A „régi” Irgalmas Kórházról fényképet tudunk bemutatni (2. ábra). Ennek a kórháznak a megvalósítása, az áldatlan budai egészségügyi állapotok miatt már 1806 óta napirenden volt. Eleinte a Császárfürdő tőszomszédságában lévő telekről volt szó, végül a délebbre lévő, úgynevezett ácstelekre esett a választás. Mint köztudott, az anyagi alapokat Marczibányi István (1752-1810) 1806-ban tett alapítványa szolgáltatta. Ó 72000 forintért megvásárolta a Császárfürdőt, és azon nyomban örök alapítvány gyanánt az Istenes Szent János rendjéhez tartozó irgalmas testvéreknek adományozta, azzal a kikötéssel, hogy „a fürdő jövedelméböl annyi beteget és annyi szerzetest tartsanak el, abányat ebböl eltartani lehet” [1].

A rend- és kórházépületet 1815 . október 4-én ünnepélyes keretek között adták át, noha először csak a „Marczibányi-szárny” készült el a szegény betegek ellátására. A városi szárny csak két évvel később épült meg, amikor is összesen 74 volt a betegágyak száma, s ez a későbbiekben még növekedett is. A korabeli fényképre tekintve, az épület nem nézett ki túl szúkösnek, az évszázad végén mégis a lebontása mellett döntöttek. Az épület egy részének elbontása már 1901 februárjában megkezdődött.

Biztosra vehető, hogy Heim Pál az álláspályázatát már a megépülő új kórházra számítva adta be, hiszen arról a fóvárosi közgyưlés már 1898-ban tárgyalt, és az új kórház terveit Kiss István építésztervező már 1900. május

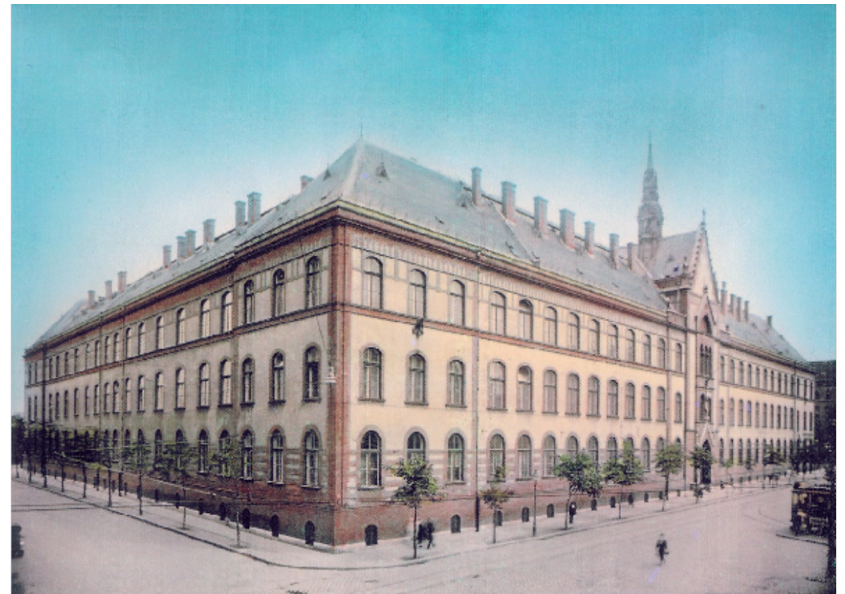

3. ábra

| Az 1903-ban megépült „új Irgalmas Kórház”

14-én bemutatta a rendnek. Tehát csak igen rövid ideig múködhetett a régi épületben.

Magyarországon 1890-től hitelt érdemlően lehet követni minden orvos múködését az évente kiadott almanachokból. Heim Pál neve először 1902-ben jelenik meg ebben, mint az Irgalmas Kórház orvosa [2]. Még az is szerepel, hogy lakása az V. kerületi Lipót körút 26. szám alatt volt, és a késóbbi évkönyvekból kiderül, hogy itt a lakáson délután 2 és 3 óra között fogadott betegeket. A másik, az ő múködésére vonatkozó fontos forrásban is először 1903-ban jelenik meg a neve [3]. Az irgalmas rend 1891 óta minden évben nagy alakú füzetet adott ki, melyben a kórházi betegellátásnak a nagyon pontos statisztikáját tette közzé. Ezekból kiderül, hogy a kórház évi 1700-2000 fekvő beteget és mintegy 30 ezer ambulánst ápolt évente.

$\mathrm{Az}$ új épületet (3. ábra), mely a kor szintjén igen modern kórháznak adott otthont, 1903 szeptemberében adták át rendeltetésének, amiról az Orvosi Hetilap is megemlékezett [4], majd illő módon a centenáriumáról is [5]. Az előző híradás, a kórház részletes leírása, így bel-, sebészeti, nőgyógyászati osztályainak ismertetése után leszögezi: „A földszinten van még egy kórterem beteg gyermekek számára 6 ággyal” - a szemészeti és a bőrgyógyászati osztály szomszédságában. Vagyis ettől fogva Heim Pál fekvő betegeket is elhelyezhetett. Mint tudjuk, erre a gyermekgyógyászatban szerencsére nem nagyon sokszor van szükség. Az ambulancia és a betegfölvétel is a bal oldali földszinti traktusban volt található. A gyermekgyógyászaton az év során 34 mütétet is végeztek, közöttük 7 garatmandula-eltávolítást. 1906-tól Heim Pálnak gyermekgyógyász munkatársa is volt, John Károly személyében.

Heim Pál az Irgalmas Kórházban zajló tevékenysége alapján érte el magántanári képesítését. A habilitációra vonatkozó egyetemi dokumentumot akkori dékánként Lenhossék Mihály (1863-1937), a háromtagú anatómusdinasztia utolsó tagja írta alá (4. ábra). 


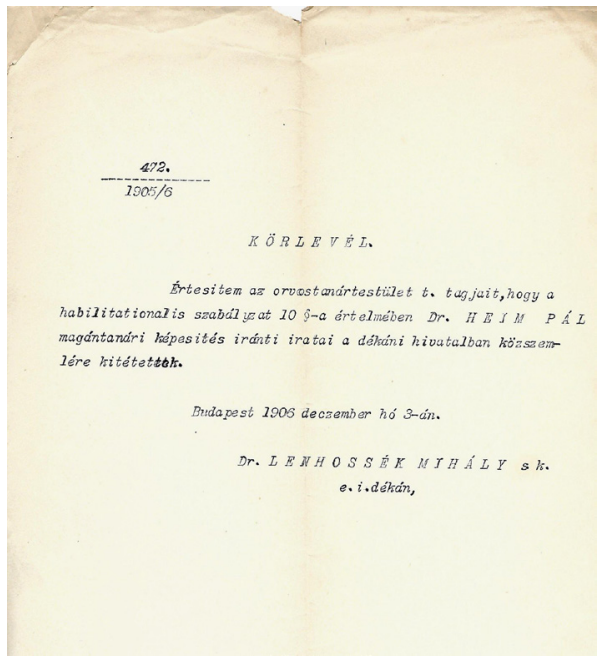

4. ábra | Dékáni körlevél 1906-ból

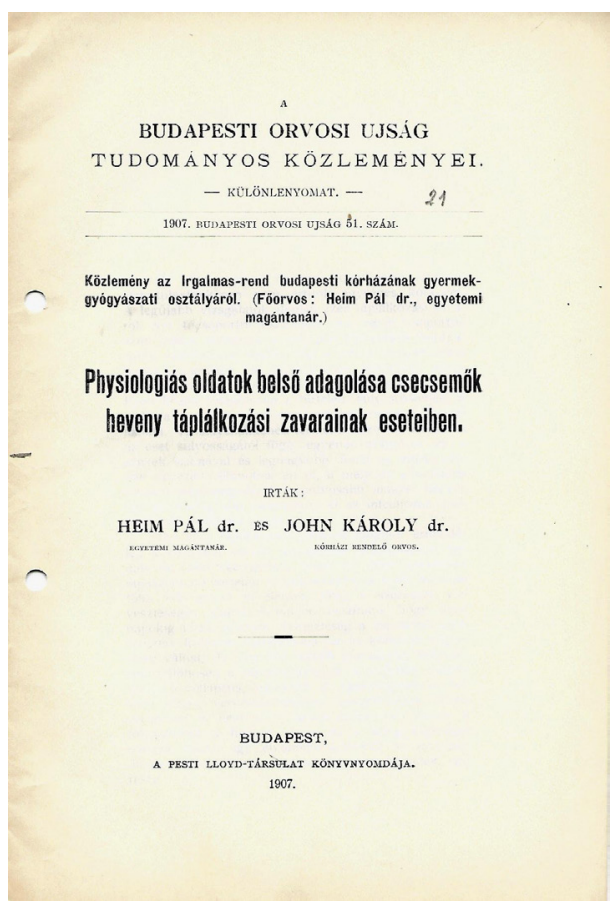

5. ábra

| Tudományos közlemény 1907-ből

A bemutatott különlenyomat (5. ábra) arról tanúskodik, hogy Heim Pál valóban végzett tudományos munkát az Irgalmas Kórházban, ső́t ezekben az években külföldi publikációi is megjelentek.

Ezen falak közül származik az „Általános haematológia" könyve is, melyet Preisich Kornél (1869-1955) gyermekgyógyásszal közösen írt, és mely 1908-ban jelent meg.

Múködése 1914 augusztusában fejeződött be, amikor is zászlóaljorvosként a frontra került. Ennek megfelelően az 1914-es „Évi kimutatás”-ban 1773, ambulánsan ellátott gyermek szerepel, de a megváltozott köntösű 1915-ös kiadásban már nincs egy gyermek sem [6]. Tehát Heim Pál távozásával befejeződött a gyermekellátás az Irgalmas Kórházban.

Heim Pál tanár a leszerelése után - a mindenütt másutt is rögzített adatok szerint - Pozsonyban, 1918-ban lett az Erzsébet Tudományegyetemen az újonnan létrehozott gyermekklinika első tanszékvezetője. Az ismert történelmi események miatt azonban az egyetemnek 1919-ben Budapestre kellett költöznie.

Heim Pál tehát összességében az Irgalmas Kórházban eltöltött 14 éves múködése alapján került katedrára. Megjegyezzük, hogy professzori kinevezésük előtt Dollinger Gyula (1849-1937) sebész és Jendrassik Ernő (1858-1921) belgyógyászok is a régi Irgalmas Kórházban tevékenykedtek.

1953-ban az Országos Gyermekvédő Intézet elnevezése Bókay János Gyermekkórházra változott. A Heim család örökké hálás azért, hogy - az igazgatói feladatokat 1953 óta ellátó Sárkány Jenő (1913-1990) javaslatára 1957-tôl Heim Pál Gyermekkórház lett az Üllői úti intézmény neve [7].

\section{Köszönetnyilvánítás}

A dokumentumok bemutatását a Heim család tette lehetővé, lévén, hogy ezek az ő birtokukban vannak.

\section{Irodalom}

[1] Tokaji-Nagy T. Working of the Hospitaller Brothers of St. John of God in Pest and Buda. [Az irgalmas rend múködése Pesten és Budán.] Mikes Kiadó, Budapest, 2001. [Hungarian]

[2] The yearbook and directory of Hungarian medical doctors. [Magyarország orvosainak évkönyve és czimtára.] „Petőfi” Újság-Könyvkiadó és Hird. Vállalat, Budapest, 1902. [Hungarian]

[3] Yearly list of the number of patients in 1903 in the Hospital of the Hospitaller Brothers of St. John of God in Budapest. [Évi kimutatás az Irgalmas-Rend Budapesti Betegápoló-Intézetében 1903. évben ápolt betegekről.] Nyomatott Bagó Márton és fiánál, Budapest [Hungarian]

[4] The new Hospital of the Hospitaller Brothers of St. John of God in Hungary. [A magyar irgalmasrend új kórháza.] Orv Hetil. 1903; 47: 635. [Hungarian]

[5] Gömör B. Centenary of the building of Polyclinic of the Hospitaller Brothers of St. John of God in Budapest. [ 100 éves a Budai Irgalmasrendi Kórház épülete.] Orv Hetil. 2003; 144: 18891890. [Hungarian]

[6] Report about the work of Hospitals and Mind Institutes of the Hospitaller Brothers of St. John of God in 1915 in the whole country. [Jelentés az Irgalmasrend budapesti, valamint a Magyar Szent Korona területén lévő többi kórházának és elmegyógyintézetének 1915. évi múködéséről.] Apostol-nyomda részvénytársaság, Budapest, 1916. [Hungarian]

[7] Personal remark from architect Pál Heim, the grandchild of Professor Pál Heim. [Személyes közlés Heim Pál unokájától, Heim Pál építészmérnöktől.]

(Gömör Béla dr., Budapest, Árpád fejedelem útja 7., 1023 e-mail: gomorbela@gmrbt.hu) 